\title{
WALT WHITMAN'S WORKING NOTES FOR THE FIRST EDITION OF LEAVES OF GRASS
}

\author{
ED Folsom
}

ONE OF THE GREAT MYSTERIES in American literary scholarship is the genesis of the first (1855) edition of Leaves of Grass. Since all but a very few of Whitman's manuscripts of the volume's twelve poems and prose preface have disappeared, critics and biographers have usually presented Leaves as an artistic immaculate conception, apparently emerging from nowhere. We are left with very few traces of the process of Whitman's creation of the book that redefined American literature. There are several passages in a couple of the poet's notebooks and some very rare holograph proto-versions of some passages of poetry. ${ }^{1}$ But the printer's copy of Whitman's manuscript has never been found, and biographers and critics have assumed that Whitman-a printer himself who tended to value his poetry only when it was set in type-simply tossed the manuscript onto the floor of the printer's shop when the compositors were done with it. Whitman told Horace Traubel in 1888, "You have asked me questions about the manuscript of the first edition. It was burned. Rome [Andrew Rome, the printer] kept it several years, but one day, by accident, it got away from us entirely - was used to kindle the fire or to feed the rag man." In a recent article in Resources for American Literary Study, Michael Feehan notes that "we know that [Whitman] participated in setting type for the first, 1855, Leaves, though we cannot be sure of the extent of his contribution. Unfortunately, we lack the manuscript, so we do not know whether Whitman designed the book while he was writing it or later on, after consultation with his publishers." ${ }^{3}$

Thanks to a remarkable manuscript preserved in the University of Texas Humanities Research Center (HRC) and reprinted on the back cover of this issue of the Walt Whitman Quarterly Review, we now have some substantive answers to such questions. Biographers and critics have always assumed that Whitman was actively involved in the design and even the typesetting of the 1855 Leaves, but the HRC manuscript provides the first actual evidence of Whitman's structuring of the book. From this manuscript, we can gain insight into the extent of Whitman's involvement in the design and production of his volume, and we can finally confirm some previously unsubstantiated claims about the first edition-including Whitman's recollection that his prose preface to the 
first Leaves was added at the last minute ("It was written hastily while the first edition was being printed in 1855"). ${ }^{4}$

The HRC manuscript - worn and soiled, after obviously spending some time on the Rome brothers' printing shop floor-consists of, on one side, a heavily revised section of a proto-version of the poem that would eventually become "Song of Myself" (key images of the eventual poem here appear in surprising juxtapositions) $;^{5}$ on the other side [see back cover] are Whitman's scribbled notes for the arrangement, size, and decoration of the 1855 Leaves. Whitman often wrote notes and drafts on the backs of various documents, including the backs of abandoned drafts of poems. During the years this manuscript has been housed in the HRC, scholars have understandably been far more interested in the side containing the draft of the poem and have ignored the cryptic and seemingly disjointed notes on the verso. But those notes cast light on the mystery of Whitman's plans for the first edition of Leaves of Grass.

The 1855 Leaves consisted of twelve poems, all untitled. On the HRC manuscript, Whitman lists the twelve poems, but in order to list them he has to give them working titles. The manuscript thus gives us our first indication that Whitman referred to his poems by name, even though he would withhold the titles in print. He gives most of the twelve poems first-line titles, a practice he would frequently employ during the rest of his career. In the manuscript, the poems appear in an order significantly different from the arrangement he finally settled on: "I celebrate myself" ("Song of Myself") came first (as it would in the printed edition), followed by "A young man came to me" (the poem that would develop into "Song of the Answerer"), "A child went forth" ("There Was a Child Went Forth"), "sauntering the pavement" ("Faces"), "great are the myths" ("Great Are the Myths"), "I wander all night" ("The Sleepers"), "Come closer to me" ("A Song for Occupations"), "Who learns my lesson complete" ("Who Learns My Lesson Complete"), "Clear the way there Jonathan" ("A Boston Ballad"), "Resurgemus" ("Europe: The 72d and 73d Years of These States"), "To think through the retrospections" ("To Think of Time"), and "Slaves" ("I Sing the Body Electric").

Whitman used these shorthand names to allow him to work out an arrangement of poems. Only one of the twelve poems had previously been published, and Whitman continued to call it by the same title under which it had originally appeared in the New York Daily Tribune"Resurgemus." Perhaps the most interesting working title is "Slaves" (the word is smudged almost beyond recognition on the manuscript), which underscores the fact that a slave auction is the setting of the poem that would become "I Sing the Body Electric." At the time he wrote these notes, "Slaves" was to be the concluding piece, a position that would have intensified the importance of the slavery issue in the book. In two cases, Whitman groups pairs of poems: "A young man came to 
me" is bracketed with "A child went forth," and "Who learns my lesson complete" is bracketed with and joined by an ampersand to "Clear the way there Jonathan." These subgroups suggest that Whitman had a hitherto unrecognized organizational plan for the book, a plan he would soon abandon in favor of what became the final arrangement.

Anticipating his notes in the 1860 "Blue Book" copy of Leaves, where he compares the number of words in his book with those in the Bible, the Iliad, the Aeneid, the Inferno, Paradise Lost, and other classics, Whitman here counts the number of letters that appear on average in "one of my closely written MS pages" (he figures 1,600) and compares it to the number of "letters in a page of Shakespeare's poems" $(1,120)$. He makes the comparison of his manuscript pages to Shakespeare's printed pages so that he can estimate how long the printed Leaves will be. Whitman's arithmetic covers the page as he calculates that his book will contain 116 pages. Either his estimates were grossly inaccurate, or, more likely, he had not yet decided on the large page size, since the first edition ended up with only 95 pages, including his ten-page prose preface (which he apparently had not yet written, since it is not mentioned in these notes). He lets us know his Leaves manuscript has "about 127 pages" (this is the first indication we have of the size of the phantom manuscript). And in one corner of the page of notes he registers that he "left with Andrew [Rome] 5 pages MS," so we know that these notes were written relatively close to the publication of Leaves, since at least some of the book was already being set in type. Since so much changed between the making of these notes and the completion of the book (including the addition of the preface and the reordering of the poems), this manuscript reveals that Whitman was actively making substantive last-minute changes-reorganizing, adding, and deleting, even while Andrew Rome was typesetting the poetry.

One of the revelations of the HRC manuscript is that Whitman divided "I celebrate myself" into five parts. Critics over the past century have argued endlessly about the partitive structure of "Song of Myself," and countless schemes have been proposed. Whitman added to the confusion by the changes he made from one edition to the next: in the first edition of Leaves, he did not section the poem except by inserting frequent spaces between groups of lines, thus creating very irregular stanzas. By 1860, he numbered each of those stanzas, almost like biblical verses, and ended up with 372 . In 1867, he added 52 section numbers and retained the stanza numbers; in 1881, he dropped the stanza numbers but kept the 52 sections. Critics have always suspected a partitive structure deeper than that indicated by Whitman's numbering schemes. Edwin Haviland Miller has summarized the various "searches for structure," beginning with William Sloane Kennedy's 1896 suggestion of a three-part structure; most of the suggestions range from four to nine parts, with five the most popular number of divisions. ${ }^{7}$ The HRC manu- 
script reveals that Whitman indeed originally divided the poem in five parts, a fact that is perhaps enough to restore one's faith in criticism.

Whitman projected that "I celebrate myself" would run 62 pages, and he indicated the number of pages in each of the five sections. Since the poem in print actually occupied only 43 pages, we need to do some math of our own to locate the approximate places where Whitman conceived of the major breaks in the poem. His notations suggest that he saw the first movement of the poem occupying what became the first fifteen sections of the 1881 "Song of Myself"; his second major division included the eventual sections 16-27; the third part ran from sections 28-34; the fourth from 35 to somewhere in section 42, and the final from section 42 (perhaps beginning with the line "This is the city .... and I am one of the citizens") through 52. That turns out to be very close to Carl F. Strauch's early (1938) suggestion that the main parts of the poem break into sections $1-18,19-25,26-38,39-41$, and $42-52 .{ }^{8}$ While Whitman's notes certainly don't determine the "correct" division, the HRC manuscript does give us our first indication that he conceived of the poem partitively and furnishes scholars with the beginnings of an author-sanctioned reading of the poem in five sections.

The HRC manuscript also indicates that Whitman originally planned to include an illustration in the book, the figure of "A large ship under her full power of steady forward motion." This note suggests that the decorations that the poet finally employed in the 1860 Leaves-a finger with a butterfly, a cloud-encircled globe, and an ocean with a rising or setting sun-were the realization of a longstanding desire to offer such visual accompaniments to his text. We don't know why he abandoned the ship ornament in the first edition-perhaps for financial reasons, or perhaps because the ship-motif had yet to surface in his poems the way it would after the Civil War, when poems like "O Captain! My Captain!" ("The ship has weather'd every rack") and "Passage to India" ("Sail forth-steer for the deep waters only, / . . And we will risk the ship, ourselves and all") were predicated on the emblematic significance of a ship under full power.

The verso of the HRC manuscript of an early version of a section of "Song of Myself" turns out, then, to be one of the most valuable and instructive of all surviving Whitman manuscripts. It is Whitman's early work sheet, the only record we have of the poet's plans for the first edition of Leaves of Grass.

\section{University of Iowa}

\section{NOTES}

1 The Humanities Research Center at the University of Texas owns several protoLeaves manuscripts. Remarkably, there has never been a thorough census of the manuscripts that anticipate the 1855 Leaves or of the manuscript versions of the poems that 
eventually appear in the book. This was one anticipated result of the projected Variorum of the Manuscripts of Leaves of Grass volumes that were to have appeared as part of the Collected Writings of Walt Whitman (New York University Press); these volumes have not yet appeared nor have they been announced. The variorum volumes in the Collected Writings (Leaves of Grass: A Textual Variorum of the Printed Poems, 3 vols. [New York University Press, 1980]) cover only book publication of the poems.

2 Horace Traubel, With Walt Whitman in Camden (1905; rpt. New York: Rowman and Littlefield, 1961), 1:92.

3 "Multiple Editorial Horizons of Leaves of Grass," Resources for American Literary Study 20 (1994), 216.

4 Edwin Haviland Miller, ed., The Correspondence (New York: New York University Press, 1961), 2:100.

5 Here is a transcription of the poetry side of the manuscript:

${ }^{\star} \operatorname{tr}$ (And to me each minute of the night and day is ehoek with something vital and visible as

\section{vital live as flesh is}

ins in here page 34 - And I say the stars are not echoes

And I perceive that the salt marsh sedgy weed has telieious odors;

And potatoes and milk afford a fit breakfast dinner of state,

And I dare not say guess the the bay mare is less than $I$ chipping bird moeking bird sings as well as 1 ,

beeause although she reads no newspaper; never learned the gamut;

And to shake my friendly right hand governors

and millionaires shall stand all day,

waiting their turns.

And on to me each acre of the earth land and sea, fbehold exhibits to me

perpetuat unending marvellous pictures;

They fill the worm-fence, and lie on the heaped stones

and are hooked to the elder and poke-weed

And to me each every minute of the night and day is filled with a [illegible] joy.

And to me the cow crunching with depressed head surpasses

every statue;

[illegible line, cut off]

This section, apparently once conceived of by Whitman as section or page 25 of the poem that would become "Song of Myself," echoes passages from numerous places in the final version of the poem (and of the 1855 preface): "And the look of the bay mare shames the silliness out of me" (p. 20 of the 1855 edition); "And the mockingbird in the swamp never studied the gamut, yet trills pretty well to me" (p. 20); "comrade of 
all who shake hands and welcome to drink and meat" (p. 24); "there is not a minute of the light or dark nor an acre of the earth or sea without it" (Preface, p. vi); "Delicate sniffs of the seabreeze . . . smells of sedgy grass and fields by the shore"(p. 42); "And mossy scabs of the wormfence, and heaped stones, and elder and mullen and pokeweed" (p. 16); "And the cow crunching with depressed head surpasses any statue" (p. 34).

6 The poem was first published in the New York Daily Tribune on June 21, 1850.

7 Edwin Haviland Miller, Song of Myself: A Mosaic of Interpretations (Iowa City: University of Iowa Press, 1989), xviii-xxviii.

8 "The Structure of Walt Whitman's 'Song of Myself,"” English fournal 27 (1938), 597-607. 